\title{
PEMANFAATAN EKSTRAK KASAR BATANG SERAI UNTUK PENGENDALIAN LARVA Crosidolomia binotalis Zell. PADA TANAMAN KUBIS
}

\author{
UTILIZATION OF CRUDE EXTRACT FRAGRANT GRASS STEM TO CONTROL \\ Crosidolomia binotalis Zell. LARVAE ON CABBAGE
}

Henny V.G Makal dan Deflly A.S. Turang

Staf Pengajar Fakultas Pertanian Universitas Sam Ratulangi Manado_95115

e-mail: henymakal@yahoo.com.

\begin{abstract}
Theresearch wasaimed to assess effect of some concentrations of lemon grass stem extract to $C$. binotalis larvae. The advantage of the research was to give information the use lemon grass stem extract as a botanical insecticide to control $C$. binotalis larvae. The result showed that after application of the lemon grass stem extract, the $C$. binotalis larvae showed symptoms such as inactive of eating, inactive of movement and eventually death of larvae $C$. binotalis. The death of larvae was showing changing of color at dorsal and ventral. The color at the dorsal became pale yellow and the color at ventral turned to light brown. The death larvae subsequently were hardened and the entire body the larvae were blackish brown. The percentage of $C$. binotalis larvae mortality increased when the concentration of lemon grass stem extract was also increased.Concentration $80 \mathrm{~g} / 50 \mathrm{ml}$ resulted $95 \%$ death of total tested larvae. It could be concluded thatlemon grass stem extract can be used to control larvae of $C$. binotalis on cabbage.
\end{abstract}

Keywords : Lemon grass, stem, extract, C. binotalis larvae, Cabbage

\section{ABSTRAK}

Penelitian ini bertujuan untuk mengetahui pengaruh beberapa konsentrasi ekstrak batang serai terhadap larva $C$. binotalis. Manfaat dari penelitian ini adalah untuk memberikan informasi tentang penggunaan ekstrak batang serai sebagai insektisida botani untuk mengendalikan larva $C$. binotalis. Gejala kematian larva C. binotalis setelah aplikasi ekstrak batang serai pada awalnya larva kelihatan gelisah, tidak aktif makan kemudian menjadi tidak aktif bergerak dan akhirnya mati. Larva yang mati terjadi perubahan warna, pada bagian dorsal berwarna kuning pucat dan bagian ventral berwarna coklat muda dan lama kelamaan seluruh tubuh mengeras dan berwarna coklat kehitaman. Hasil penelitian menunjukan bahwa persentase mortalitas larva $C$ binotalis meningkat seiring dengan meningkatnya konsentrasi ekstrak batang serai yang diaplikasikan. Pada konsentrasi ekstrak batang serai $80 \mathrm{~g} / \mathrm{ml}$ menyebabkan mortalitas sebesar $95 \%$ dari keseluruhan larva uji. Berdasarkan hasil ini, ekstrak batang serai dapat digunakan untuk mengendalikan larva $\mathrm{C}$. binotalis pada kubis.

Kata kunci: Batang serai, Larva C. binotalis, Kubis

Eugenia Volume 17 №. 1 April 2011 


\section{PENDAHULUAN}

Kubis (Brassica oleracea var. capitata L.) merupakan sayuran terpenting di Indonesia, namun demikian dalam pembudidayaanya banyak kendala yang dihadapi antara lain adalah masalah hama dan penyakit. Menurut Sastrosiswojo dan Setiawati (1993), salah satu hama penting yang menyerang tanaman kubis adalah $C$. binotalis. Hasil penelitian di Sulawesi Utara khususnya di Kota Tomohon menunjukkan bahwa tingkat kerusakan tanaman kubis yang diakibatkan oleh hama C. binotalis mencapai 40\% (Rante, $d k k$. 1995).

Adanya serangan hama pada tanaman kubis, menyebabkan para petani berusaha melindungi tanaman dari kerusakan hama dengan menggunakan bahan kimia seperti insektisida sintetik. Pada mulanya insektisida sintetik sangat membantu petani untuk melindungi tanaman dari serangan hama tetapi pada akhirnya insektisida tersebut menimbulkan berbagai dampak negatif terhadap lingkungan dan manusia itu sendiri.

Penggunaan bahan kimia alami dari tanaman bioaktif tidak menimbulkan pencemaran lingkungan, baik tanah, air dan udara, tidak meninggalkan residu di alam, mudah dilaksanakan serta biaya pelaksanaannya relatif murah (Sastroutomo, 1992). Kardinan (2004), menyatakan bahwa tanaman serai (Andropogon nardus L) adalah salah satu tanaman yang dapat digunakan sebagai insektisida alami untuk pengendalian hama tanaman. Penggunaan ekstrak batang serai sebagai insektisida botanis merupakan salah satu alternatif pengendalian hama yang ramah lingkungan.

Penelitian ini bertujuan untuk mengetahui pengaruh ekstrak batang serai terhadap larva $C$. binotalis.

\section{METODE PENELITIAN}

Penelitian ini dilaksanakan di laboratorium Hama Tumbuhan Fakultas Pertanian Universitas Sam Ratulangi Manado. Rancangan percobaan yang digunakan adalah RAL (Rancangan Acak Lengkap), dengan 4 (empat) ulangan dan 5 (lima) perlakuan adalah sebagai berikut : 1) control 2) konsentrasi $20 \mathrm{gr} / 50 \mathrm{ml}$ air 3) konsentrasi $40 \mathrm{gr} / 50$ $\mathrm{ml}$ air 4) konsentrasi $60 \mathrm{gr} / 50 \mathrm{ml}$ air 5) konsentrasi $80 \mathrm{gr} / 50 \mathrm{ml}$ air.

Kegiatan yang dilakukan adalah : a) Mengumpulkan larva-larva C. binotalis dari lapang yakni dari pertanaman kubis di Rurukan Kota Tomohon. b) Larva yang sudah terkumpul dipelihara sampai menjadi dewasa. c) Sebanyak 15 serangga dewasa dipindahkan ke dalam kurungan kasa di dalamnya diletakkan 5 polybag tanaman kubis sebagai tempat imogo meletakkan telur. d) Setelah imago meletakkan telur, tanaman kubis tetap dipelihara dalam kurungan untuk menunggu telur menetas menjadi larva. Larva yang digunakan dalam pengujian ini adalah larva instar kedua. Karena larva instar kedua ini masih berada di luar krop.

\section{Penyediaan Ekstrak Batang Serai}

Serai sebanyak 2000 gram dibersihkan dari kotoran yang menempel dengan cara mencuci kemudian dikering anginkan selama 12 jam dan di potong-potong selanjutnya diblender. Timbang serai sebanyak $20 \mathrm{gr}$ untuk konsentrasi $20 \mathrm{gr} / 50$ $\mathrm{ml}$ air, $40 \mathrm{gr} / 50 \mathrm{ml}$ air, $60 \mathrm{gr} / 50 \mathrm{ml}$ air dan $80 \mathrm{gr} / 50$ $\mathrm{ml}$ air. Masing-masing konsentrasi dilakukan perendaman selama 24 jam untuk mendapatkan larutan ekstak.

\section{Aplikasi Akstrak Batang Serai}

Daun kubis yang digunakan adalah daun kubis muda yang di tanam di green house. Dua helai daun kubis muda di cuci kemudian di celupkan dalam masing-masing konsentrasi ekstrak batang serai. Daun kubis yang digunakan untuk kontrol dicelupkan dalam aquades steril dengan cara yang sama. Sebanyak 20 larva C. binotalis instar 2 hasil perbanyakan dipuasakan selama 5 jam kemudian dimasukkan dalam wadah yang sudah beralaskan kertas tissu dalam keadaan lembab dan diberi makan daun kubis yang telah dicelupkan dalam masing-masing konsentrasi ekstrak batang serai

Pengamatan dilakukan 24 jam setelah perlakuan sampai kematian mencapai lebih dari $60 \%$. 
Hal-hal yang diamati adalah: Gejala yang terlihat pada larva setelah aplikasi dan jumlah larva yang mati dan hidup

\section{HASIL DAN PEMBAHASAN}

Hasil penelitian menunjukkan bahwa gejala kematian yang terlihat pada larva $C$. binotalis setelah pengaplikasian ekstrak batang serai yakni pada awalnya larva kelihatan seperti gelisah, dan mulai tidak aktif makan, lama-kelamaan larva menjadi tidak aktif bergerak dan selanjutnya sudah mulai terlihat ada larva yang mati. Larva-larva yang mati pada tubuhnya terjadi perubahan warna dimana pada bagian dorsal berwarna kuning pucat dan bagian ventral berwarna coklat muda dan lama-kelamaan di seluruh tubuh terjadi pengerasan, berubah warna menjadi coklat kehitaman. Hal ini terjadi karena larva memakan daun kubis yang sudah diberi perlakuan ekstrak batang serai, yang merupakan racun akut.

Tarumingkeng (1992), menyatakan bahwa simptomatologis serangga yang terkena dengan racun perut diantaranya adalah mengalami kegelisahan (anxiety) dan larva terlihat seperti muntah. Jadi semakin tinggi konsentrasi ekstrak batang serai yang diaplikasikan menyebabkan semakin banyak larva yang mati.

Hasil pengamatan mortalitas larva $C$. binotalis setelah aplikasi dengan ekstrak batang serai pada konsentrasi $20 \mathrm{gr} / 50 \mathrm{ml}, 40 \mathrm{gr} / 50 \mathrm{ml}, 60$ $\mathrm{gr} / 50 \mathrm{ml}, 80 \mathrm{gr} / 50 \mathrm{ml}$ dan kontrol, menunjukkan angka yang berbeda. Hasil analisis varians, menunjukkan bahwa di antara perlakuan terdapat perbedaan yang sangat nyata. Rata-rata persentase mortalitas larva $C$. binotalis yang diaplikasikan dengan ekstrak batang serai pada berbagai konsentrasi dapat dilihat pada tabel 1 .

Dari tabel 1 terlihat bahwa ekstrak batang serai memberikan pengaruh terhadap mortalitas larva C. binotalis. Persentase kematian larva meningkat seiring dengan meningkatnya konsentrasi ekstrak batang serai, hal ini berkaitan dengan sifat senyawa-senyawa seperti sitral, sitronelal, geraniol, sitroneol, nerol, dan farnesol yang terdapat di dalam jaringan tanaman serai yang bila konsentrasi tinggi dapat membunuh serangga, sehingga dapat menghambat pertumbuhan dan perkembangan serangga. Karr dan Coast, 1992 dalam Lee, dkk. 1997).

Data persentase mortalitas larva menandakan bahwa ekstrak batang serai dapat digunakan sebagai insektisida botanis untuk mengendalikan hama $C$. binotalis. Dikatakan demikian karena pada konsentrasi $80 \mathrm{gr} / 500 \mathrm{ml}$ sudah mampu mengendalikan populasi $C$. binotalis sebesar $95 \%$ dari total populasi serangga uji. Prijono (1994), mengemukakan bahwa suatu ekstrak dikatakan efektif bila perlakuan dengan ekstrak tersebut dapat mengakibatkan tingkat kematian $>90 \%$.

Mengenai hubungan antara konsentrasi ekstrak batang serai dengan jumlah larva yang mati dihubungkan dengan kisaran waktu, dapat dilihat pada gambar 1 bahwa mortalitas larva terjadi pada jam ke-24 dan meningkat terus sampai pada jam ke-96, seiring dengan meningkatnya konsentrasi ekstrak batang serai yang diaplikasikan.

Tabel 1. Rerata Persentase Mortalitas Larva C. binotalis

(Table 1. Average Mortality Percentace of C.binotalis larvae)

\begin{tabular}{ccccccc}
\hline $\begin{array}{c}\text { Konsentrasi Ekstrak } \\
\text { Batang Serai }\end{array}$ & \multicolumn{7}{c}{ Rerata Persentase Mortalitas Larva } \\
& \multicolumn{7}{c}{ Pada Jam ke - } \\
\cline { 2 - 7 } Kontrol & 12 & 24 & 36 & 48 & 60 & 72 \\
$20 \mathrm{gr} / 50 \mathrm{ml}$ & 0 & 0 & 0 & 0 & $5 \mathrm{a}$ & $5 \mathrm{a}$ \\
$40 \mathrm{gr} / 50 \mathrm{ml}$ & 0 & 0 & 0 & 22,5 & $30 \mathrm{c}$ & $35 \mathrm{c}$ \\
$60 \mathrm{gr} / 50 \mathrm{ml}$ & 0 & 0 & 5 & 25 & $45 \mathrm{~d}$ & $52,5 \mathrm{~d}$ \\
$80 \mathrm{gr} / 50 \mathrm{ml}$ & 0 & 0 & 2,5 & 27,5 & $50 \mathrm{e}$ & $85 \mathrm{e}$ \\
\hline
\end{tabular}

Keterangan : Angka yang diikuti oleh huruf yang sama tidak menunjukkan perbedaan 
Dari data persentase kumulatif mortalitas larva C. binotalis, dapat dilihat bahwa kematian larva justru pertama kali terjadi pada perlakuan dengan konsentrasi $20 \mathrm{gr} / 500 \mathrm{ml}$ dan bukan terjadi pada konsentrasi yang lebih tinggi. Hal ini mungkin berkaitan dengan keragaman ginetik dari setiap individu (larva) dalam suatu populasi. Menurut Corbet (1984), bahwa setiap individu dalam suatu populasi berbeda kecepatan dan cara untuk menetralisir racun yang termakan, maka pantaslah terjadi kematian pertama kali pada perlakuan dengan konsentrasi ekstrak yang lebih rendah.

Kematian larva yang terjadi pada kontrol, kemungkinan lebih disebabkan oleh tekanan dari faktor lingkungan di dalam laboratorium atau bahkan karena akibat dari perlakuan pada tahap persiapan atau sementara penelitian berlangsung. Sunjaya (1970), mengatakan bahwa serangga akan terhambat pertumbuhan dan perkembangannya atau mati apabila faktor lingkungan tempat hidupnya tidak mendukung baik dari faktor fisis atau dari faktor makanan.

Dalam hal ini ada larva yang masih mampu bertahan hidup sampai pada periode waktu tertentu dan bahkan ada larva yang dapat hidup Mortalitas sampai ke stadia pupa tetapi tidak lama kemudian mati. Hal ini terjadi sebab semakin tinggi kadar racun yang ada di dalam tubuh suatu organisme, semakin sulit suatu organisme menghambat atau menetralisir racun yang ada di dalam tubuhnya. Menurut Wigglesworth (1974), di saat memasuki stadia pupa, banyak sekali cadangan glikogen dan protein yang diperlukan untuk pembentukan kokon, dengan demikian aktivitas biokimia lebih banyak diarahkan untuk pembentukan senyawa-senyawa tersebut, sehingga aktivitas metabolisme untuk menghambat atau menetralisir racun yang ada di dalam tubuhnya menjadi menurun dan akibatnya pupa yang terbentuk akhirnya mati (tidak dapat hidup sampai ke stadia imago).

Berdasarkan pada pengamatan, ternyata kematian larva $C$. binotalis tidak semuanya terjadi secara langsung setelah aplikasi tetapi kematian terjadi secara berangsur-angsur sampai pada stadia pupa. Ini menunjukkan bahwa senyawasenyawa yang terkandung di dalam ekstrak batang serai selain dapat membunuh secara langsung, juga dapat mempengaruhi perkembangan larva $C$. binotalis sampai ke stadia pupa.

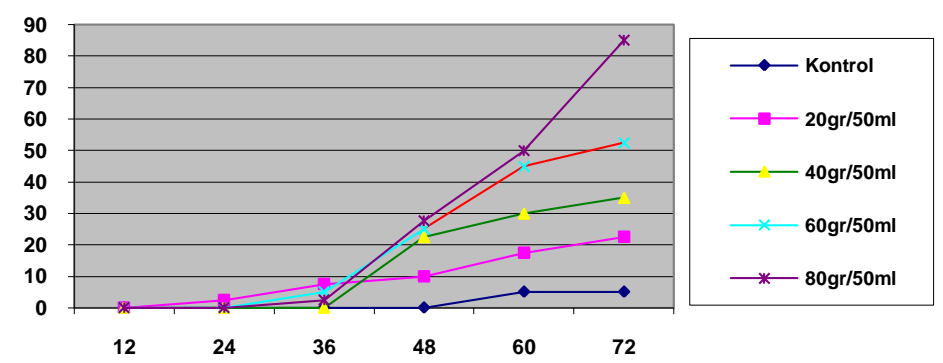

0

$$
\text { Waktu Pengamatan (jam) }
$$

Gambar 1. Hubungan antara Konsentrasi Ekstrak Batang Serai dengan Mortalitas Larva dengan Kisaran Waktu Pengamatan

(Figure 1. The Relationship Between Concentration Lemon Grass Extract and Mortality of Larvae Acording Observation Time) 


\section{KESIMPULAN}

Persentase mortalitas larva C. binotalis meningkat seiring dengan meningkatnya konsentrasi ekstrak batang serai yang diaplikasikan. Konsentrasi ekstrak batang serai 80 $\mathrm{gr} / 50 \mathrm{ml}$ dapat digunakan sebagai insektisida botanis untuk mengendalikan hama $C$. binotalis pada kondisi laboratorium, karena pada konsentrasi ini dapat mengakibatkan kematian sebesar 95\% dari total populasi serangga uji.

\section{DAFTAR PUSTAKA}

Corbet, J.R.K., Wright, A.C. Baillie. 1984 The Biochemical Mode of Action of Pesticides. Academic Press London.

Kalshoven, L.G.E. 1981. Pest of Crops in Indonesia. PT. Ichtiar Baru Van Hoove. Jakarta.

Kardinan, A. 1999. Pestisida Nabati Ramuan dan Aplikasi. PT. Penebar Swadaya. Jakarta.

Lee, S.R., Tsao C. Peterson, J.R. Coast. 1977. Insecticidal Activity of Monoterpenoida to
Western Corn Roofworm (Coleoptera ; Chrysomelidae) Twospotted Spider Mite (Acri : Tetranychidae) and House Fly (Diptera : Muscidae). Journal of Entomology, Volume 90, number 4. The Entomological Sosiety of America.

Prijono, D. 1994. Pedoman Praktikum Teknik Pemanfaatan Insektisida Botanis. Bogor.

Rante, C., D.T. Sembel, M. Meray dan N.N. Wanta. 1995. Penerapan Pengendalian Hama Terpadu (PHT) Pada Tanaman Kubis di Kecamatan Tomohon, Kabupaten Minahasa. Eugenia 1 (4) Tahun XI Oktober 1995.

Sastroutomo, S.T. 1992. Pestisida Dasar-dasar dan Dampak Penggunaannya. PT. Gramedia Pustaka Utama. Jakarta.

Tarumingkeng, R.C. 1992. Insektisida, Sifat Mekanisme, Kerja dan Dampak Penggunaannya. Ukrida. Jakarta.

Wigglesworth, V.B. 1974. Insect Physiology. Chapman and Hall. London. 